\title{
PENAMBAHAN KULIT ARI BIJI KEDELAI HASIL FERMENTASI MENGGUNAKAN EM-4 DALAM FORMULASI RANSUM PELLET BROILER TERHADAP FRAKSI SERAT
}

\author{
Anwar Efendi Harahap*, Hidayati, Sri Devi dan Bakhendri Solfan \\ Program Studi Peternakan Fakultas Pertanian dan Peternakan, UIN Sultan Syarif Kasim Riau, Telp (0761) \\ 562051, Email*: harahapa258@gmail.com
}

\begin{abstract}
Abstrak
Sumber bahan baku pakan dapat diperoleh dari berbagai limbah, salah satunya limbah industri yaitu kulit biji ari kedelai, pengolahan kulit biji ari kedelai berpotensi sebagai ransum broiler berbentuk pellet. Penelitian ini bertujuan mengevaluasi fraksi serat pelletbroiler berbahan kulit ari biji kedelai hasil fermentasi (KABKF) menggunakan Effective Microorganism-4 dengan lama penyimpanan berbeda. Metode penelitian yang gunakan adalah metode eksperimen dengan Rancangan Acak Lengkap (RAL) yang terdiri dari 5 perlakuan 4 ulangan. Peubah yang diukur dalam penelitian ini adalah kandungan fraksi serat yang meliputi $\operatorname{NDF}(\%)$, ADF (\%), ADL (\%), hemiselulosa (\%) dan selulosa (\%). Hasil penelitian ini menunjukkan semakin lama penyimpanan ransum pellet broiler dapat menurunkan kandungan NDF (75,50\%- 53,31\%), ADF (57,57\%- 41,56\%), dan ADL (12,33\%-5,73\%) serta belum dapat meningkatkan kandungan hemiselulosa $(11,86 \%-17,93 \%)$ dan selulosa (42,39- $29,78 \%$. Kesimpulan penelitian ini bahwa ransum pellet dengan penyimpanan 8 minggu memiliki perlakuan terbaik dalam menurunkan kandungan NDF\%, ADF\%, dan ADL
\end{abstract}

Kata kunci: Fraksi Serat, Fermentasi, Pelet, Kulit Ari Biji Kedelai

\begin{abstract}
Source of feed raw materials can be obtained from various wastes, one of which is industrial waste is soybean seed, processing soybean seed, which has the potential as broiler ration in the form of pellets. This study aims to evaluate the fraction of broiler pellet fiber fermented soybean seed (KABKF) using Effective Microorganism4 with different storage times. The research method used was an experimental method with a completely randomized design consisting of 5 treatments and 4 replications. The variables in this study were the fiber fraction content which included NDF (\%), ADF (\%), ADL (\%), hemicellulose (\%) and cellulose (\%). The results of this study indicate that the longer the storage of broiler pellet rations can reduce the NDF content $(75.50 \%$ - 53.31\%), ADF (57.57\% - 41.56\%), and ADL (12.33\% - 5.73\%). ) and had not been able to increase the content of hemicellulose (11.86\% - 17.93\%) and cellulose $(42.39-29.78 \%$. The conclusion is that pellet ration with 8 weeks of storage has the best treatment in reducing the content of NDF\%, ADF\%, and ADL\%
\end{abstract}

Keywords: Fiber Fraction, Fermented, Pellets, Soybean Seed.

\section{PENDAHULUAN}

Kulit ari biji kedelai merupakan limbah industri pembuatan tempe yang didapat setelah melalui proses perebusan dan perendaman kacang kedelai. Setelah melalui proses ini maka kulit ari akan terpisah dan biasanya akan dibuang begitu saja. Kulit ari ini masih potensial dimanfaatkan sebagai pakan ternak mengingat kandungan nutrisi yang tinggi. Menurut Rohmawati, dkk.(2015) kulit ari biji kedelai memiliki kandungan protein kasar $14,45 \%$, lemak kasar 3,04\%, abu $3,15 \%$, serat kasar $47,01 \%$, energi metabolis $3.060,48 \mathrm{kkal} / \mathrm{kg}$. Menurut Ningsih (2017), Dinas Perindustrian dan Perdagangan Kota Pekanbaru melaporkan terdapat 37 industri tahu dan tempe yang sudah berkembang sejak Tahun 2009 - 2012. Kendala utama yang dihadapi dalam penggunaan kulit ari biji kedelai ini sebagai pakan unggas adalah kandungan serat kasarnya yang tinggi. Serat kasar merupakan komponen bahan pakan yang sulit dicerna oleh unggas. Keberadaan fraksi ini akan mempengaruhi kecernaan dan penyerapan zat-zat makanan lainnya, sehingga protein dalam ransum tidak dapat dimanfaatkan secara optimal untuk pembentukan jaringan tubuh sehingga pertumbuhan ternak terganggu (Satie, 1991). Oleh karena itu perlu adanya pengolahan untuk menurunkan fraksi serat kulit ari biji kedelai dengan cara fermentasi. Fermentasi merupakan proses metabolik esensial dengan melibatkan kerja bakteri tanpa adanya oksigen (O2) dimana produk yang terbentuk karena fermentasi adalah asam organik, gas, atau alkohol (Mani, 2018). Proses fermentasi agar dapat berlangsung dengan baik perlu adanya bahan tambahan salah satunya Effective Microorganism-4. EM4 dapat 
mendegredasikan kandungan serat dan lignin, karena memiliki kemampuan untuk menghasilkan enzim selulase dan ligninase yang diproduksi oleh mikroba yang terdapat didalamnya terutama bakteri Lactobacillus dan Actinimycetes (Santoso dan Aryani, 2007; Satria dan Nurhasanah, 2010), sehingga kondisi ini memungkinkan kulit ari biji kedelai fermentasi dijadikan sebagai pakan broiler

Proses pemberian pakan fermentasi kulit ari biji kedelai dengan EM4dalam ransum broiler berbentuk mash memiliki kekurangan yaitu banyak pakan yang terbuang menyebabkan usaha produksi ternak tidak efisien akibat biaya pakan yang tidak efisien, oleh karena itu perlu alternatif pengolahan lanjutan yaitu pellet. Salah satu cara untuk meningkatkan penggunaan kulit ari biji kedelai dalam pakan perlu pengolahan bahan pakan menjadi pellet. Pellet merupakan hasil modifikasi dari mash yang dihasilkan dari pengepresan, sehingga pellet menjadi lebih keras (Jahan et al., 2006). Lebih lanjut Harahap dkk., (2020) menyatakan bahwa pellet merupakan pengolahan pakan secara fisik yang memformulasikan berbagai jenis bahan pakan. Pellet ini memiliki keunggulan selain efisien dalam pemeberiaannya terhadap broiler juga memiliki kemampuan pakan yang tahan simpan. Menurut Wigati (2009), proses penyimpanan adalah suatu kegiatan yang dilakukan untuk menahan atau menunda suatu barang sebelum barang tersebut dipakai tanpa merubah bentuk barang tersebut. Penelitian ini bertujuan mengevaluasi kandungan fraksi serat ransum pellet berbahan kulit ari biji kedelai hasil fermantasi menggunakan EM4 yang disimpan dengan waktu yang berbeda

\section{BAHAN DAN METODE}

\section{Bahan}

Bahan yang digunakan dalam penelitian ini adalah kulit ari biji kedelai, dedak jagung, kosentrat, dan dedak padi. Tepung tapioka sebagai bahan perekat agar dalam proses pencetakan bahan dapat menyatukan atau merekat dengan kuat dan sempurna. Bahan untuk analisis fraksi serat yaitu aquadest, Natrium-Lauryl Sulfat, Tittriplex III, Natrium borat, $\mathrm{H} 2$, Disodium Hydrogen Phosphate (Na2HPO4), $\mathrm{H}_{2} \mathrm{SO}_{4} 1 \mathrm{~N}$, CTAB
(Cetyl- Trimethyl Ammonium Bromide), Oktanol, dan Alkohol 96\%. Alat yang digunakan adalah mesin grinder, baskom, sendok pengaduk, kantong plastik, mesin cetak pellet/pelleter, neraca analitik, karung. Alat untuk analisis fraksi serat yaitu gelas piala $1000 \mathrm{ml}$, spatula, pipet tetes, timbangan analitik, fibertex yang dilengkapi dengan hot extraction dan cold extraction, pemanas, oven listrik, tanur, desikator dan gelas ukur.

\section{Metode}

Metode penelitian yang dilakukan adalah metode eksperimen dengan Rancangan Acak Lengkap (RAL) yang terdiri dari 5 perlakuan 4 ulangan untuk setiap lama penyimpanan dengan rincian sebagai berikut: A0 : Lama penyimpanan Ransum Pellet Kulit Ari Biji Kedelai Fermentasi (KABKF) 0 minggu, A1: Lama penyimpanan 2 minggu, A2 : Lama penyimpanan 4 minggu, A3 : Lama penyimpanan Ransum Pellet KABKF 6 minggu, A4 : Lama penyimpanan 8 minggu.

\section{Peubah yang diukur}

Peubah yang diukur dalam penelitian ini adalah kandungan fraksi serat yang meliputi NDF(\%), ADF (\%), ADL (\%), Hemiselulosa (\%) dan Selulosa (\%)

\section{Prosedur Penelitian \\ Fermentasi Kulit Ari Biji Kedelai}

Persiapan bahan seperti kulit ari biji kedelai yang sudah ditimbang sesuai dengan jumlah yang kebutuhan yaitu $3 \mathrm{~kg}$ berat segar yang akan dicampurkan dengan EM4. Selanjutnya sebelum melakukan fermentasi tahapan yang harus dilakukan adalah membuat starter fermentasi kulit ari biji kedelai dengan mencampurkan 7,5 mL EM4 dan 7,5 $\mathrm{mL}$ Molases kemudian ditambahkan air sebanyak $85 \mathrm{~mL}(1: 1: 10)$. Setelah itu diaduk sampi searah jarum jam hingga homogen dan diamkan selama 48 jam (Pasaribu dkk, 1998) dan tahap akhir yaitu mencampur bahan kulit ari biji kedelai dengan stater EM4 yang sudah dibuat, kemudian bahan dimasukan kedalam ember/plastik dan ditutup rapat. Kulit ari biji kedelai difermentasi selama 7 hari.

\section{Pembuatan Pellet}

Kulit ari biji kedelai fermentasi dijemur dibawah sinar matahari hingga kering. Jika semua bahan telah mengering langkah selanjutnya adalah pengilingan.Setelah seluruh bahan menjadi tepung dicampurkan 
Agrisaintifika

Jurnal Ilmu-Ilmu Pertanian

Vol. 4, No. 2, 2020

Harahap, et al. 2020

seluruh bahan pakan pembuat pellet hingga rata, selanjutnya bahan pakan dicetak menggunakan mesin pencetak pellet. Bahan pakan yang sudah menjadi pellet selanjutnya dijemur hingga kering kemudian disimpan selama 0, 2, 4, 6 dan 8 minggu. Penyimpanan menggunakan plastik polyenthilene yang ditutup rapat menyebabkan kemungkinan udara masuk kedalam plastik relatif kecil,kemudian dianalisis fraksi serat. Susunan ransum dapat dilihat pada Tabel 1, 2 dan 3

Tabel 1. Kandungan nutrisi bahan pakan penyusun pellet

\begin{tabular}{lcccccc}
\hline \multicolumn{1}{c}{ Bahan Baku } & \multicolumn{7}{c}{ Kandungan zat makanan } \\
\cline { 2 - 7 } & PK & Energi & Lemak & SK & Ca & P \\
\hline Dedak jagung** & 10,82 & 3350,00 & 7,09 & 1,89 & 0,05 & 0,31 \\
Dedak padi halus $^{*}$ & 11,91 & 3000,00 & 5,14 & 11,89 & 0,14 & 0,60 \\
Tepung KABKF* $^{*}$ & 12,30 & 3268,00 & 5,75 & 19,62 & 0,00 & 0,00 \\
Konsentrat** $^{* *}$ & 39,09 & 2641,00 & 5,07 & 2,03 & 0,63 & 0,01
\end{tabular}

Sumber: *Laboratorium IImu Nutrisi dan Kimia Fakultas Pertanian dan Peternakan UIN Suska Riau, 2017, ${ }^{* *}$ Laboratorium Peternakan Fakultas Peternakan Universitas Muhammadiyah Malang, 2003,

*** Laboratorium Nutrisi Ikan Universitas Riau 2016.

Tabel 2. Kebutuhan zat makanan broiler

\begin{tabular}{lc}
\hline \multicolumn{1}{c}{ Zat makanan } & Jumlah kebutuhan \\
\hline Energi metabolis (kkal/kg) & Minimal 2900 \\
Protein kasar (\%) & Minimal 18,0 \\
Lemak kasar (\%) & Maksimal 8,0 \\
Serat kasar (\%) & Maksimal 6,0 \\
Kalsium (\%) & $0,90-1,20$ \\
Phospor (\%) & $0,6-1,0$ \\
\hline
\end{tabular}

Sumber : BSN (Badan Standar Nasional) SNI 01-3931-2006

Tabel 3. Formulasi ransum pellet KABKF penelitian

\begin{tabular}{lcc}
\hline & Bahan baku & Formulasi \\
\hline Dedak jagung & & 48,00 \\
Dedak padi halus & 10,00 \\
Tepung KABKF & & 20,00 \\
Konsentrat & Total & 22,00 \\
\hline & & 100 \\
\hline PK \% & 18,36 \\
Energi & 3142,62 \\
Lemak \% & 6,18 \\
SK \% & 6,47 \\
Ca \% & 0,18 \\
P \% & 0,21 \\
\hline
\end{tabular}




\section{HASIL DAN PEMBAHASAN}

\section{Neutral Detergent Fiber}

Rataan kandungan NDF pellet broiler berbahan kulit ari biji kedelai hasil fermentasi menggunakan EM4 dengan lama penyimpanan berbeda dapat dilihat pada Tabel 4.

Tabel 4. Rataan kandungan NDF pellet broiler berbahan kulit ari biji kedelai hasil fermentasi menggunakan EM4 (\%).

\begin{tabular}{cc}
\hline Lama penyimpanan (minggu) & NDF \\
\hline 0 & $75,50^{\mathrm{a}} \pm 0,71$ \\
2 & $67,40^{\mathrm{b}} \pm 0,23$ \\
4 & $65,05^{\mathrm{c}} \pm 0,80$ \\
6 & $56,66^{\mathrm{d}} \pm 1,59$ \\
8 & $53,31^{\mathrm{e}} \pm 0,46$
\end{tabular}

Keterangan : Superskrip yang berbeda pada kolom yang sama menunjukkan perbedaan sangat nyata $(P<0,01)$. Data yang ditampilkan adalah Rataan \pm Standar Deviasi.

Berdasarkan hasil Tabel 4. metabolisme mikroba. Lebih lanjut menunjukkan bahwa kandungan NDF pellet dikemukakan Arief (2001) bahwa peregangan kulit ari biji kedelai hasil fermentasi ikatan ligin-selulosa dan lignin hemiselulosa menggunakan EM4 dengan lama penyimpanan berbeda sangat nyata $(P<0,01)$ menurunkan kandungan NDF. Semakin lama penyimpanan kandungan NDF pellet semakin menurun. Hal ini kemungkinan karena adanya kinerja mikroorganisme yang memanfaatkan substrat bahan pada pellet, terutama kandungan serat kasar sehingga berpengaruh terhadap penurunan kandungan NDF. Menurunnya kandungan NDF menunjukkan bahwa selama berlangsungnya penyimpanan terjadi fermentasi yang mengakibatkan penguraian ikatan lignin dan hemiselulosa (Nursiang, 2017). Hal ini sesuai dengan Hidayat dkk. (2006) bahwa proses-proses yang terdapat pada fermentasi selama penyimpanan meliputi produksi sel mikroba, produksi enzim mikroba, dan produksi hasil menyebabkan isi sel (protein, karbohidrat, mineral-mineral) dan terikat akan larut dalam larutan neutral detergent.Penurunan kandungan NDF penelitian ini relatif sama dengan penelitian Ali dkk., (2015) pada pakan pellet yang menggunakan kombinasi daun pelepah sawit dan Indigofera.zollingeriana, dimana semakin banyak proporsi Indigofera.zollingeriana maka kandungan NDF yang dihasilkan semakin menurun (66,04\%-33,96\%)

\section{Acid Detergent Fiber}

Rataan kandungan ADF pellet broilerberbahan kulit ari biji kedelai hasil fermentasi menggunakan EM4 dengan lama penyimpanan berbeda masing-masing perlakuan dapat dilihat pada Tabel 5 .

Tabel 5. Rataan kandungan ADF pellet broiler berbahan kulit ari biji kedelai hasil fermentasi menggunakan EM4 dengan penyimpanan berbeda (\%).

\begin{tabular}{cc}
\hline Lama penyimpanan (minggu) & ADF \\
\hline 0 & $57,57^{\mathrm{a}} \pm 0,59$ \\
2 & $51,71^{\mathrm{b}} \pm 0,39$ \\
4 & $50,60^{\mathrm{c}} \pm 0,24$ \\
6 & $43,06^{\mathrm{d}} \pm 0,42$ \\
8 & $41,56^{\mathrm{e}} \pm 0,83$ \\
\hline
\end{tabular}

Keterangan: $\quad$ Superskrip yang berbeda padaa kolom yang sama menunjukkan perbedaan sangat nyata $(\mathrm{P}<0,01)$. Data yang ditampilkan adalah Rataan \pm Standar Deviasi. 
Berdasarkan Tabel 5 menunjukkan bahwa kandungan ADF ransum pellet berbahan kulit ari biji kedelai hasil fermentasi menggunakan EM4 dengan lama penyimpanan berbeda sangat nyata $(P<0,01)$ terhadap kandungan ADF yang dihasilkan. Penurunan kandungan ADF pellet pada lama penyimpanan 8 minggu diduga juga berkaitan dengan kandungan NDF. Hal ini sesuai pendapat Ali (2014) menyatakan bahwa ADF adalah bagian dari fraksi serat dimana unsur utamanya adalah selulosa. Kandungan ADF menggambarkan kualitas dinding sel hijauan, bagian ini terdiri dari selulosa dan lignin. Menurunnya kandungan ADF maka pencernaan pellet kulit ari biji kedelai hasil fermentasi menggunakn EM4 akan meningkat. Hal ini sesuai dengan pendapat Ruddel et al.,(2002) bahwa persentasi ADF yang tinggi akan menurunkan daya cerna bahan pakan.Kandungan ADF pada penelitian ini berkisar antara 41,56 - 57,57 \% lebih tinggi dari penelitian Jati $d k k$., (2017) pada ransum pellet unggas menggunakan tepung indigoferazollingeriana dengan nilai ADF berkisar antara 9,42 - 15,87\%

\section{Acid Detergent Lignin}

Rataan kandungan ADL pellet ayam ras pedaging berbahan kulit ari biji kedelai hasil fermentasi menggunakan EM4 dapat dilihat pada Tabel 6.

Tabel 6. Rataan kandungan ADL pellet broiler berbahan kulit ari biji kedelai hasil fermentasi menggunakan EM4 dengan penyimpanan berbeda (\%).

\begin{tabular}{cc}
\hline Lama penyimpanan (minggu) & ADL \\
\hline 0 & $12,33^{\mathrm{a}} \pm 0,93$ \\
2 & $9,91^{\mathrm{b}} \pm 0,77$ \\
4 & $8,04^{\mathrm{c}} \pm 0,23$ \\
6 & $7,27^{\mathrm{c}} \pm 0,37$ \\
8 & $5,73^{\mathrm{d}} \pm 0,68$ \\
\hline
\end{tabular}

Keterangan : Superskrip yang berbeda pada kolom yang sama menunjukkan perbedaan sangat nyata $(P<0,01$. Data yang ditampilkan adalah Rataan \pm Standar Deviasi.

Berdasarkan Tabel 6 menunjukkan bahwa kandungan $\mathrm{ADL}$ ransum pellet berbahan kulit ari biji kedelai hasil fermentasi menggunakan EM4 dengan lama penyimpanan berpengaruh sangat nyata $(P<0,01)$ terhadap kandungan $A D L$ yang dihasilkan. Semakin lama penyimpanan kandungan ADL pellet semakin menurun. Hal ini diduga lignoselulase yang dihasilkan mikroba anaerob mampu merombak kandungan lignin karena lama fermentasi cukup untuk mikroba anaerob mendegradasi lignoselulosa pada substrat. Hal ini sesuai menurut Astuti dkk.(2011) semakin lama pemeraman semakin menurunkan kandungan fraksi serat, hal ini diduga disebabkan oleh mikroorganisme mengurai isi sel pada saat pemeraman, semakin lama diperam semakin banyak isi sel yang terurai. Kandungan ADL yang dihasilkan pada penelitian ini berkisar antara $5,73 \%$ - $12,33 \%$, relatif sama dengan penelitian Qomaruzzaman (2018) dengan kandungan ADL berkisar antara 3,94\% $6,50 \%$ pada pellet berbahan daun indigofera dengan penambahan ampas sagu menggunakan level tepung tapioka yang berbeda

\section{Hemiselulosa}

Rataan kandungan hemiselulosa pellet ayam ras pedaging berbahan kulit ari biji kedelai hasil fermentasi menggunakan EM4 dengan lama penyimpanan dapat dilihat pada Tabel 7.

Berdasarkan Tabel 7 menunjukkan bahwa kandungan hemiselulosa ransum pellet berbahan kulit ari biji kedelai hasil fermentasi menggunakan EM4 dengan lama penyimpanan berbeda sangat nyata $(P<0,01)$ terhadap kandungan hemiselulosa yang dihasilkan. Kualitas hemiselulosa dengan lama penyimpanan 0 minggu memiliki nilai tertinggi sebesar 17,93\% dibandingkan dengan hemiselulosa pada lama penyimpanan 2 minggu 15,68\%, 4 minggu $14,41 \%$, 6 minggu $13,61 \%$, dan 8 minggu $11,86 \%$. Semakin lama penyimpanan kandungan hemiselulosa pellet semakin menurun. Hal ini diduga karena mikroorganisme belum optimal memanfaatkan kandungan hemiselulosa pada 
inti sel sehingga kandungan hemiselulosa

tidak mengalami peningkatan.

Tabel 7. Rataan kandungan hemiselulosa pellet ayam pedaging berbahan kulit ari biji kedelai hasil fermentasi menggunakan EM4 (\%).

\begin{tabular}{cc}
\hline Lama Penyimpanan (Minggu) & Hemiselulosa \\
\hline 0 & $17,93^{\mathrm{a}} \pm 0,58$ \\
2 & $15,68^{\mathrm{b}} \pm 0,23$ \\
4 & $14,41^{\mathrm{c}} \pm 0,81$ \\
6 & $13,61^{\mathrm{c}} \pm 1,19$ \\
8 & $11,86^{\mathrm{d}} \pm 1,13$ \\
\hline
\end{tabular}

Keterangan : Superskrip yang berbeda pada kolom yang sama menunjukkan perbedaan sangat nyata $(\mathrm{P}<0,01) \mathrm{Data}$ yang ditampilkan adalah Rataan \pm Standar Deviasi.

Hal ini didukung Said (1996) menyatakan bahwa hemiselulosa dapat difermentasi oleh beberapa mikroorganisme yang mampu menggunakan gula pentosa sebagai subtratnya.Menurunya kandungan hemiselulosa pada lama penyimpanan 8 minggu $(11,86 \%)$ juga diduga karena semakin lama penyimpanan akan semakin banyak hemiselulosa dipecah menjadi gula pentosa sehingga kandungan hemiselulosa menurun.
Sesuai dengan pernyataan Syarifuddin (2009) kandungan hemiselulosa setelah ensilase lebih rendah dibaningkan sebelum ensilase, karena hemiselulosa dipeceh menjadi gula pentosa selama terbentuknya ensilase.

\section{Selulosa}

Rataan kandungan selulosa pellet broiler masing-masing perlakuan dapat dilihat pada Tabel 8.

Tabel 8. Rataan kandungan selulosa pellet broiler berbahan kulit ari biji kedelai hasil fermentasi menggunakan EM4 (\%).

\begin{tabular}{cc}
\hline Lama Penyimpanan (Minggu) & Selulosa \\
\hline 0 & $42,39^{\mathrm{a}} \pm 1,93$ \\
2 & $40,24^{\mathrm{b}} \pm 3,41$ \\
4 & $35,27^{\mathrm{c}} \pm 1,56$ \\
6 & $32,49^{\mathrm{d}} \pm 0,14$ \\
8 & $29,78^{\mathrm{e}} \pm 0,38$
\end{tabular}

Keterangan: Superskrip yang berbeda pada kolom yang sama menunjukkan perbedaan sangat nyata $(\mathrm{P}<0,01)$. Data yang ditampilkan adalah Rataan \pm Standar Deviasi.

Berdasarkan Tabel 8. memperlihatkan bahwa kandungan selulosa ransum pellet berbahan kulit ari biji kedelai hasil fermentasi menggunakan EM4 dengn lama penyimpanan berbeda sangat nyata $(\mathrm{P}<0,01)$ terhadap kandungan selulosa yang dihasilkan. Semakin lama penyimpanan kandungan selulosa pellet semakin menurun. Hal ini diduga mikroba tidak dapat berkerja secara maksimal mencapai inti sel. Terhambatnya aktivitas mikroba disebabkan oleh dinding sel yang terlignifikasi tidak cukup berpori untuk memungkinkan difusi enzim terutama selulase, sehingga mikroba hanya dapat menyerang permukaan dari dinding sel saja (Tomaszewska et al., 1993). Didukung oleh Mirwandhono (2006) bahwa pertumbuhan mikroba telah mencapai fase pertumbuhan eksponensial maka laju pertumbuhan populasinya mengalami penurunan.

\section{SIMPULAN}

Lama penyimpanan 8 minggu memiliki perlakuan terbaik dalam menurunkan kandungan NDF\%, ADF\%, dan ADL\%, namun belum mampu meningkatkan kandungan hemiselulosa $\%$ dan selulosa $\%$ pada ransum ;pellet Broiler dengan penambahan kulit ari biji kedelai hasil fermentasi menggunakan EM-4

\section{DAFTAR PUSTAKA}

Ali A, M.Tarmizi dan D. Febrina. 2017. Fraksi Serat Pelet Silase Pelepah Kelapa Sawit (Elaeis guineensis) dan Indigofera (Indigofera zollingeriana) dengan Komposisi yang Berbeda. Prosiding 
Seminar Nasional Teknologi Peternakan dan Veteriner. hlm. 648 - 65

Ali, A. 2014. Sistem Penanaman Campuran Rumput Dan Leguminosa Dilahan Gambut Untuk Produksi Hijauan Pakan Ternak Berkelanjutan. Disertasi. Institut Pertanian Bogor.

Arief, R. 2001. Pengaruh Penggunaan Jerami pada Amoniasi Terhadap Daya Cerna NDF, ADF, dan ADS dalam Ransum Domba Lokal. Jurnal Agroland. 8(2) : 208215.

Astuti, T., Sari Y., Zulkarnaini. 2011. Pengaruh Fermentasi Kulit Pisang dengan Mikroorganisme Lokal (MOL) Pada Lama Pemeraman dan Sumber MOL yang Berbeda Terhadap Kandungan Fraksi Serat Sebagai Pakan Ternak. Universitas Muara Bungo dan Politani. Padang.

Harahap, S, A.E Harahap dan E. Irawati. 2020. Kualitas Fisik Pellet Ayam Pedaging dengan Penambahan Tepung Kulit Pisang Kapok dalam Ransum pada Lama Penyimpanan Berbeda. Jurnal Nutrisi Ternak Tropis. 3 (2) 71-80

Hidayat, N., M.C. Padaga, dan Suhartini. 2006. Mikrobiologi Industri. Penerbit Andi. Yogyakarta.

Jahan , M. S., Asaduzzaman, M. And Sarkar, A. K., 2006. Performance of broiler fed on mash, pellet and crumble. Int. J. Poultry Sci. 5(3) : 265-270.

Jati P.Z, T. Adelina dan D. A. Mucra. 2017. Kandungan Fraksi Serat Ransum Pellet Unggas dengan Penggunaan Tepung Indigoferazollingeriana.

Peternakan. 14 (1) : 11-17

Mani A. 2018. Food Preservation by Fermentation and Fermented food products. International Journal of Academic Research \& Development. 1 : $51-57$

Mirwandhono, E., Irawati B., dan Darwanto S. 2006. Uji Nilai Nutrisi Kulit Ubi Kayu yang di Fermentasi Dengan Aspergillus
Niger.JurnalAgribisnis Peternakan. 2 (3) : 91-95

Ningsih, O. 2017. Dampak Kenaikan Harga Kedelai terhadap Industri Tahu dan Tempe di Kota Pekanbaru. JOM Fekon. 4(1):994-1003

Pasaribu T, A. P. Sinurat, T. Purwadaria, Supriyati dan H. Hamid. 1998. Peningkatan Nilai Gizi Lumpur Sawit melalui Proses Fermentasi. Pengaruh Jenis Kapang, Suhu dan Lama Proses Enzimatis. JITV. 3 (4): 237-242

Qomaruzzaman, M. 2018. Fraksi Serat Pakan Pellet Berbahan Daun Indigofera Zollingeriana dengan Penambahan Ampas Sagu Menggunakan Level Tepung Tapioka yang Berbeda. Skripsi. Program Studi Peternakan. Fakultas Pertanian dan Peternakan. Universitas Islam Negeri Sultan Syarif Kasim Riau. Pekanbaru. Riau.

Rohmawati, D. Djunaidi H. Irfan danWidodo Eko. 2015. Nilai Nutrisi Tepung Kulit Ari Biji Kedelai dengan Level Inokulum Ragi Tape dan Waktu Inkubasi Berbeda. J. Ternak Tropika. 16 (1):30-33.

Said. 1996. Penanganan dan Pemanfaatan Limbah Kelapa Sawit. Trubus. Agriwidya. Bogor.

Satie, D.L. 1991. Kulit Ari Biji Kedelai sebagai Campuran Ransum Broiler. Jurnal Poultry Indonesia. 42 : 9.

Syarifuddin, N. A. 2009. Nilai Gizi Rumput Gajah Sebelum dan Sesudah Ensilase Pada Berbagai Umur Pemotongan. Jurnal Fakultas Peternakan Universitas Jambi. Jambi

Tomaszewaska, M. W., I. M. Mastika, A. Djajanegara, S. Gardiner dan T.R. Wiradarya. 1993. Produksi Kambing dan Domba di Indonesia. Universitas Sebelas Maret. 
Wigati, D. 2009. Pengaruh Jenis Kemasan dan Lama Penyimpanan terhadap Serangan Serangga dan Sifat Fisik Ransum Broiler Starter Berbentuk
Crumble. Skripsi. Departemen IImu Nutrisi dan Teknologi Pakan. Fakultas

Peternakan. Institut Pertanian Bogor. Bogor. 